\title{
Research of the Influence of Marine Residual Fuel Composition on Sedimentation Due to Incompatibility
}

\author{
Radel Sultanbekov ${ }^{1}$, Shamil Islamov ${ }^{2}$, Dmitry Mardashov ${ }^{2}\left(\right.$ ) , Ilia Beloglazov ${ }^{3, *(1)}$ and Tor Hemmingsen ${ }^{4}(\mathbb{C}$ \\ 1 Department of Transport and Storage of Oil and Gas, Saint Petersburg Mining University, \\ 199106 Saint Petersburg, Russia; Sultanbekov_RR@pers.spmi.ru \\ 2 Department of Development and Operation of Oil and Gas Fields, Saint Petersburg Mining University, \\ 199106 Saint Petersburg, Russia; Islamov_ShR@pers.spmi.ru (S.I.); Mardashov_DV@pers.spmi.ru (D.M.) \\ 3 The Department of Automation of Technological Processes and Production, Saint Petersburg Mining \\ University, 199106 Saint Petersburg, Russia \\ 4 Faculty of Science and Technology, University of Stavanger, 4036 Stavanger, Norway; tor.hemmingsen@uis.no \\ * Correspondence: Beloglazov_II@pers.spmi.ru
}

Citation: Sultanbekov, R.; Islamov, S.; Mardashov, D.; Beloglazov, I.; Hemmingsen, T. Research of the Influence of Marine Residual Fuel Composition on Sedimentation Due to Incompatibility. J. Mar. Sci. Eng. 2021, 9, 1067. https://doi.org/ 10.3390/jmse9101067

Academic Editors: María

Dolores Esteban Pérez

José-Santos López-Gutiérrez, Vicente Negro and M. Graça Neves

Received: 6 September 2021

Accepted: 26 September 2021

Published: 29 September 2021

Publisher's Note: MDPI stays neutral with regard to jurisdictional claims in published maps and institutional affiliations.

Copyright: (c) 2021 by the authors. Licensee MDPI, Basel, Switzerland. This article is an open access article distributed under the terms and conditions of the Creative Commons Attribution (CC BY) license (https:// creativecommons.org/licenses/by/ $4.0 /)$

\begin{abstract}
The article shows studies of the problem of active sediment formation during mixing of residual fuels, caused by the manifestation of incompatibility. To preserve the quality and reduce sediment formation during transshipment, storage, and transportation of marine residual fuels, a laboratory method for determining the compatibility and stability of fuels has been developed, which makes it possible to determine the quantitative characteristics of the sediment formation activity. According to the method developed, laboratory studies have been carried out to determine incompatible fuel components and the influence of composition on the sedimentation process. Tests were carried out to determine the quality indicators and the individual group composition of the fuel samples. Based on the results of the studies, the dependences of the influence of normal structure paraffins in the range from 55 to $70 \mathrm{wt}$. \% and asphaltenes in the range from 0.5 to $3.5 \mathrm{wt}$. \% in the fuel composition on the sedimentation activity due to incompatibility were obtained. To obtain a convenient tool that is applicable in practice, a nomogram has been developed on the basis of the dependences obtained experimentally. It was also determined that, after reaching the maximum values of sediment formation with a further increase in the content of n-paraffins, saturation is observed, and the value of the sediment content remains at the same level. Maximum total sediment values have been found to depend on asphaltene content and do not significantly exceed them within $10 \%$. The results of the research presented in this article allow laboratory and calculation to determine the possibility of incompatibility and to preserve the quality of marine residual fuels.
\end{abstract}

Keywords: incompatibility; stability; total sediment; precipitation; marine residual fuels; mixing; storage; group composition

\section{Introduction}

Today, when providing civil ships and vessels with fuel, there are certain difficulties associated with the quality characteristics of marine residual fuels, namely in connection with the tightening of requirements for the sulfur content due to the introduction by the International Maritime Organization of a new convention in MARPOL 73/78 Annex VI [1]. Since 1 January 2020, according to this convention, it is regulated that, throughout the world's oceans, the sulfur content in marine fuels should not exceed $0.5 \%$ of the mass. As a result, the permissible sulfur content in marine fuels has decreased 7 times, from $3.5 \%$ to $0.5 \%$ of the mass. Oil refineries in Russia are currently not able to fully provide a new type of fuel with sulfur up to $0.5 \%$, as this requires a significant restructuring of the refining process and requires significant capital investments [2-4]. Therefore, in order to meet the demand for a new type of marine fuels, bunkering companies are actively carrying out operations to mix fuels to obtain the required quality indicators $[5,6]$. That is why there is a 
sharp increase in the share of composite fuels for ship installations, which, in turn, increases the risks of active sedimentation, which is caused by the manifestation of incompatibility of fuels $[7,8]$.

In this regard, during storage and transportation, especially marine, the problem of active sedimentation of residual and mixed fuels caused by loss of stability is relevant [9]. According to the international standard ISO 8217 for fuel quality, the content of the total sediment should not exceed $0.1 \%$ of the mass. Note that there are risks of incompatibility even when mixing the same brand of fuels due to differences in composition. The incompatibility of residual fuels is manifested due to the occurrence of strong intermolecular interactions, which are caused by a change in the structural group individual composition, as well as a change in the concentration ratio of high-molecular compounds of residual fuels $[10,11]$. All this contributes to the formation of associates of molecules, colloidal particles by volume of various shapes and structures $[12,13]$.

There are several laboratory ways and methods to determine the compatibility and stability of residual fuels before actual mixing in tanks and storages: the spot method GOST 33365 and ASTM D 4740, determination of xylene and toluene equivalents in accordance with GOST 33288 and GOST 33296, patent RU 2305836 C1, patent RU 2444005 C1, and international application No. WO 2018185520 [14-17]. However, after their consideration and application, these methods and techniques have been found to have a high error rate and low precision, so that they have not been widely used in practice [18].

The first investigations of sediment formation due to loss of stability were carried out in order to study the compounding process of various types of heavy fuels. For the first time, in 1951, Martin used the term "incompatibility", to describe the sharp increase in precipitation observed when mixing "pure" fuel with a low content of total sediment [19].

Holmes et al. and other research groups have studied the manifestation of incompatibility when mixing fuels. These authors have developed basic theoretical provisions but have not formulated clear recommendations to preserve the quality of fuels during mixing to address this problem [20-23].

Other research groups have carried out studies to determine the stability and compatibility of mixtures of marine fuels. The main results of these studies are the acquisition of theoretical information and the development of a three-phase diagram to determine the stability of the mixture of marine residual fuels (Figure 1).

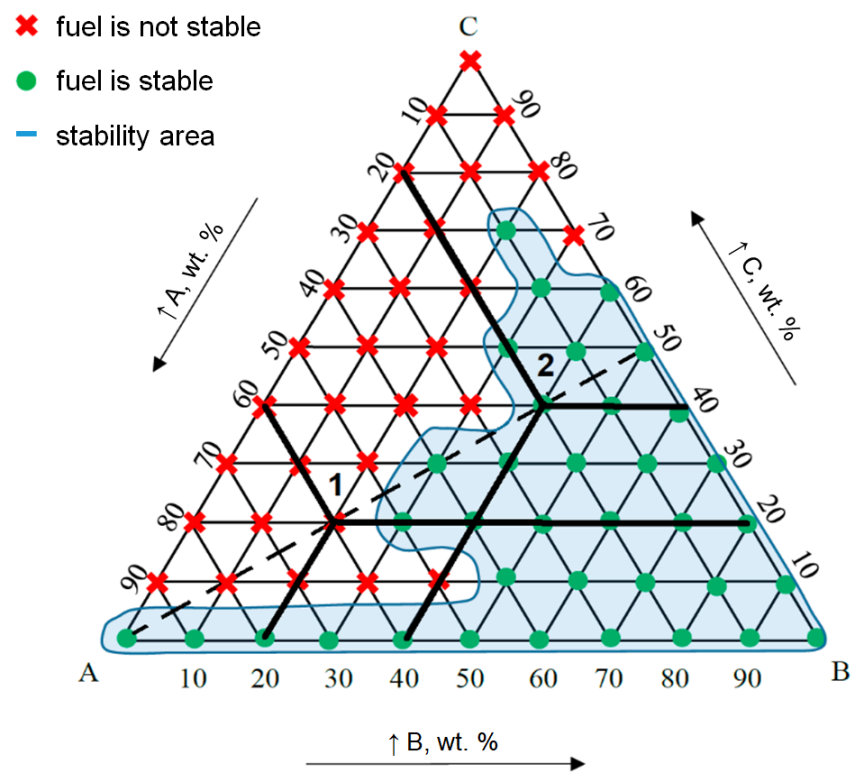

Figure 1. Three-phase stability diagram of marine residual fuel A-B-C [24-26].

The stability assessment method allows the establishment of areas of stability and the determination of the boundary content of each fuel component in a multicomponent 
mixture, taking into account the use of incompatible components, where the remaining quality requirements for marine fuels are also taken into account, such as density, viscosity, sulfur content, etc.

The compatibility evaluation criteria in this method were adopted by the authors according to ISO 10307-2:2009, which regulates the determination of fuel incompatibility if the total sediment value is greater than 0.1 . Less than this value, the fuel composition is compatible and stable. Therefore, when mixing fuels with a total sediment value greater than $0.1 \%$, this method will not allow assessing the stability of fuels.

The study of this problem was carried out in the specially created company "Soluble Solutions", which was directed by Wiehe $[27,28]$. Researchers have identified more than 100 incompatible oil components that are on the U.S. market. Unfortunately, due to commercial secrets, basic information (species, physicochemical properties, and qualitative characteristics) cannot be disclosed, and information is not publicly available.

However, exact dependences of the mutual influence of hydrocarbon composition on sedimentation due to the manifestation of incompatibility have not been obtained.

Analysis of existing research and patent documents showed that extensive laboratory studies were carried out to study the process of sedimentation. Most of the research focuses on sedimentation in oil [29]. It is also worth noting that precise, reliable, and practically applicable methods for predicting the potential incompatibility of mixtures that allow assessing the activity of sedimentation have not yet been developed. There is no dependency between the mutual influence of hydrocarbon composition on sediment formation, and many researchers limited themselves to only general recommendations for maintaining quality.

\section{Materials and Methods}

In the present work, the marine residual fuels of the KMS, TSU-80, TSU-380. and M-100 brands (according to the classification ISO 8217, corresponding to the brands RMD80—sample No.1, RMD-80—sample No.2, RMG-380—sample No.3, and RMK 700—sample No.4) were used as research objects, which are shown in Figure 2. The samples were taken according to GOST 2517 from storage and railway tanks. The choice of the marine residual fuels presented is based on the different group composition, which allows the required fuel composition to be obtained when mixing to determine the influence of each group of residual fuels composition on the compatibility and stability of the fuel system. Isostructured paraffins predominate in the TSU-80 fuel and normal paraffins in the KMS fuel. The TSU-380 and M-100 fuel brands contain heavier components, including asphaltenes and resins. By combining the composition, it is possible to determine the influence of each component on the stability of the fuel system.

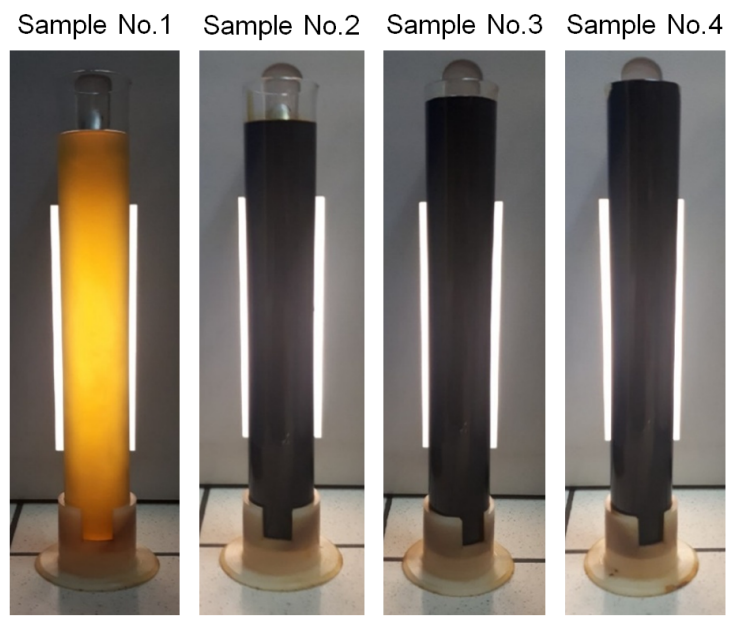

Figure 2. Samples of marine residual fuels. 
Modern techniques and the corresponding laboratory equipment base of Scientific Center "Issues of Processing Mineral and Technogenic Resources" of Saint Petersburg Mining University were used to determine the main indicators of the quality of marine fuels, namely density, kinematic viscosity, PMCC flashpoint, sulfur and water content, pourpoint, total sediments accelerated (TSA), and total sediments potential (TSP) values.

In the work, for ease of labeling and conducting research, the components are distributed by numbers:

- Sample No.1-Compound oils grade A type 1 (KMC);

- Sample No.2-Fuel for TSU-80 marine installations (RMD-80);

- $\quad$ Sample No.3-Fuel for TSU-380 marine installations (RMG-380);

- Sample No.4-Residual oil fuel M-100, low ash (RK-700).

The group hydrocarbon composition of the samples was analyzed using actual methods, namely the SARA analysis, which is based on the separation of the petroleum products studied into saturated hydrocarbons, aromatic compounds, resins, and asphaltenes, according to their polarity and solubility (Figure 3).

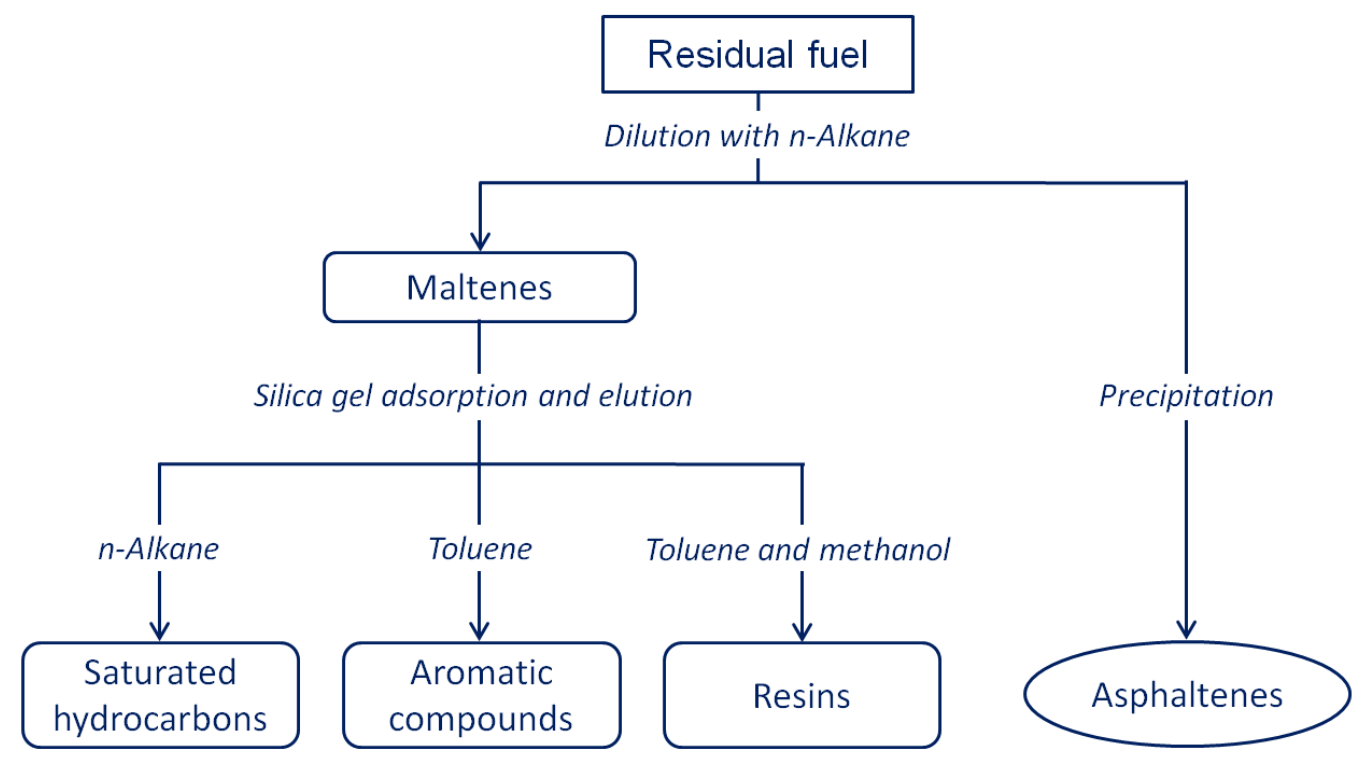

Figure 3. Residual fuel dilution scheme to determine the group composition of fuels.

Analysis of the group hydrocarbon composition of fuels was carried out on the laboratory gas chromatograph "Gradient-M" with a heat conductivity detector by liquid adsorption chromatography on glass columns with a height of $30 \mathrm{~cm}$ and a diameter of 1.2-1.4 mm [30,31].

According to the presented method, $\mathrm{n}$-heptane was added for the separation of asphaltenes in a ratio of 1:40 by mass. The remaining maltenes are further separated by passing through a chromatographic column with adsorbent. The absorbent was a modified silica gel of the ASC brand, which is precalcined for $4 \mathrm{~h}$ at $150{ }^{\circ} \mathrm{C}$. A complex mixture of solvents with gradient-displacement mode of supply was used as eluates. This method allows testing of samples for paraffin-naphthenic, aromatic hydrocarbons, resins, and asphaltenes [32,33].

Due to the newly developed method for determining fuel compatibility and stability, it became possible to determine the quantitative characteristics of sedimentation [34]. The essence of the method is as follows: initially, the contents of the total sediment of each component of the mixture are determined; further, the components are mixed in the required proportions, after which the value of the total sediment of the fuel mixture is determined, on the basis of which the compatibility index (CI) is calculated $[35,36]$. 
The CI of a fuel mixture is defined as the sum of the average total sediment of the fuel mixture components $\left(S_{a v}\right)$ and the convergence value (r). Calculation formula (1) is presented below [35]:

$$
\mathrm{CI}=\mathrm{S}_{\mathrm{av}}+\mathrm{r} \text {. }
$$

If the actual TSP values of the $S_{a v}$ mixture are greater than CI, then the fuel mixture is incompatible; if $S_{\mathrm{av}}$ is less than $\mathrm{CI}$, then the fuel mixture is compatible and stable during long-term storage.

For example, consider the results of laboratory tests carried out according to the method developed. Samples No.1 and 3 are mixed in a 1:1 ratio. The result is a manifestation of fuel incompatibility, which contributes to a sharp increase in total sediment, the TSP value $=0.17 \mathrm{wt}$. $\%$, where TSP is the total sediment after aging a sample of residual fuel for $24 \mathrm{~h}$ at $100{ }^{\circ} \mathrm{C}$ under prescribed conditions (Figure 4 ).
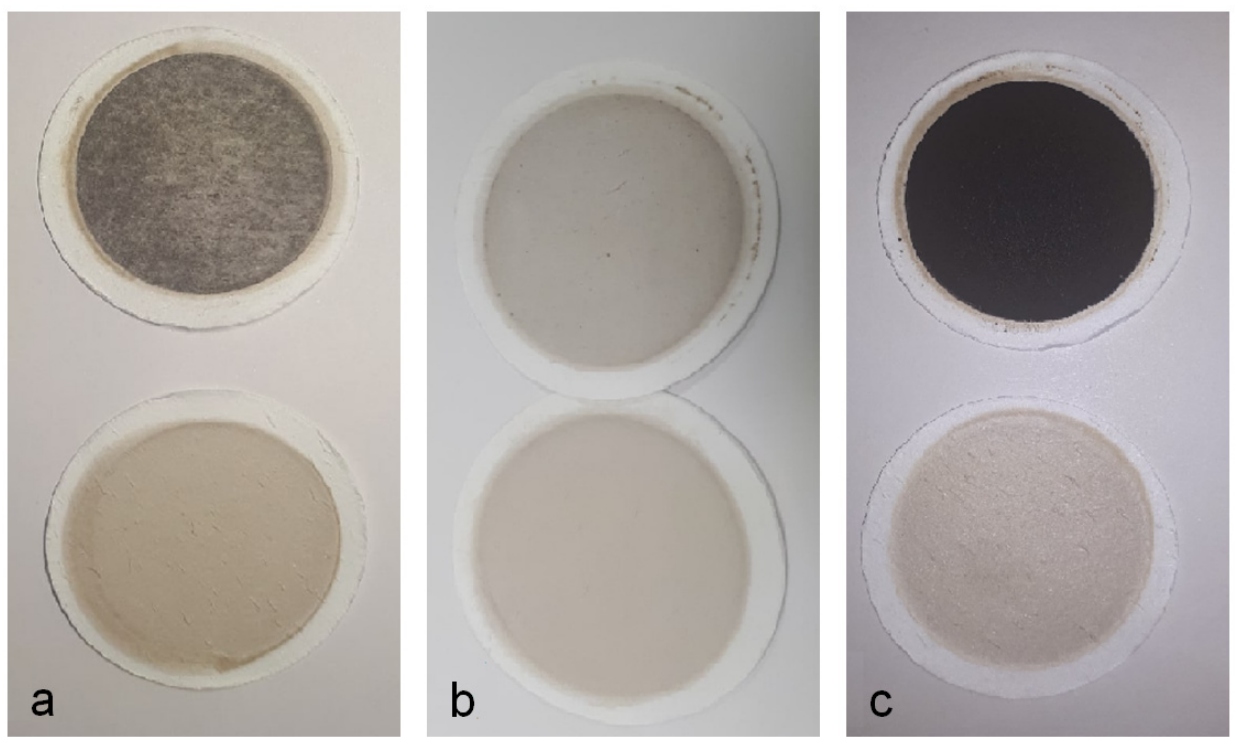

Figure 4. Filters after filtration and determination of total sediment content: (a)—sample No.1; (b)—sample No.2; (c)—mixture of samples No.1 and No.2.

Figure 4 shows as an example filter after thermostating and filtration of $10 \mathrm{~g}$ of fuel components (Figure 4a,b) and fuel mixture (Figure 4c) of samples No.1 and 3 with an asphaltene content of $1.0 \mathrm{wt}$. \% and n-paraffins $63 \mathrm{wt}$. \%. According to the developed method [35] on the basis of GOST 33360-2015, the samples are filtered through 2 filters and then washed with a mixture of heptane (85\%) and toluene (15\%). The test shall be considered valid if the lower filter is light-colored. Even visually, a high content of the total sediment in the fuel mixture is visible, since after mixing there is a loss of stability of the dispersed system and coagulation of molecules, which leads to the precipitation of asphaltene compounds. The arithmetic mean of two measurements to determine the amount of TSP value in the mixture is $0.17 \mathrm{wt}$. \%. Hence, $\mathrm{r}=0.123 \sqrt{\mathrm{X}}=0.05 \%$, which means $C I=S_{a v}+r=\left(\frac{0.02+0.01}{2}\right)+0.05=0.065$. As a result, $0.17 \geq 0.065$, i.e., $S_{a v} \geq C I$, it follows that this mixture of fuels is incompatible, which causes active sedimentation.

Theoretical studies of the influence of the composition of residual fuels on sediments were carried out for laboratory experiments. On the basis of known theoretical data, sediments in the fuel system are primarily influenced by changes in n-alkane concentration, as well as asphaltene content. Theoretical evidence of no influence of isoparaffins on the loss of stability of Asphaltenes was taken into account in the design of the experiment, as was the minimal influence of aromatic hydrocarbons with less than $10 \mathrm{wt} \%$ in the fuel system [32]. The correlation-regression analysis performed confirmed these data. All these factors allowed us to optimize the number of laboratory tests required. 


\section{Results}

Laboratory tests have been performed according to arbitration methods to determine the quality indicators of the fuel samples considered. The results of the tests are presented in Table 1.

Table 1. Quality indicators of residual fuels.

\begin{tabular}{|c|c|c|c|c|c|c|c|}
\hline \multirow{2}{*}{ No. } & \multirow{2}{*}{ Indicator Name } & \multirow{2}{*}{$\begin{array}{l}\text { Unit of Mea- } \\
\text { surement }\end{array}$} & \multirow{2}{*}{$\begin{array}{l}\text { Regulation of } \\
\text { the Test Method }\end{array}$} & \multicolumn{4}{|c|}{ Result } \\
\hline & & & & Sample No.1 & Sample No.2 & Sample No.3 & Sample No.4 \\
\hline 1 & Density at $15^{\circ} \mathrm{C}$ & $\mathrm{kg} / \mathrm{m}^{3}$ & ISO 12185 & 833.5 & 901.0 & 956.0 & 976.0 \\
\hline 2 & $\begin{array}{c}\text { Kinematic } \\
\text { viscosity at } 50{ }^{\circ} \mathrm{C}\end{array}$ & $\mathrm{mm}^{2} / \mathrm{s}$ & $\begin{array}{l}\text { GOST } 33 \\
\text { ISO } 3104\end{array}$ & 12.1 & 34.5 & 321.5 & 680.1 \\
\hline 3 & $\begin{array}{l}\text { Flashpoint } \\
\text { PMCC }\end{array}$ & ${ }^{\circ} \mathrm{C}$ & $\begin{array}{l}\text { GOSTREN } \\
\text { ISO } 2719 \\
\end{array}$ & 181.0 & 110.0 & 98.0 & 110.0 \\
\hline 4 & $\begin{array}{l}\text { Sulfur mass } \\
\text { fraction }\end{array}$ & $\%$ & $\begin{array}{l}\text { GOST R } 51947 \\
\text { ISO } 8754 \\
\end{array}$ & 0.004 & 0.046 & 1.276 & 2.668 \\
\hline 5 & Pourpoint & ${ }^{\circ} \mathrm{C}$ & ASTM D 6749 & 26.0 & 10.0 & 16.0 & 20.0 \\
\hline 6 & $\begin{array}{c}\text { Mass fraction of } \\
\text { water }\end{array}$ & $\%$ & $\begin{array}{l}\text { GOST R } 51946 \\
\text { ISO } 3733\end{array}$ & - & - & 0.05 & 0.1 \\
\hline 7 & $\begin{array}{l}\text { Total sediment } \\
\text { accelerated } \\
\text { (TSA) }\end{array}$ & $\%$ & $\begin{array}{c}\text { GOST R 50837.6 } \\
\text { ISO 10307-2 }\end{array}$ & 0.01 & 0.01 & 0.02 & 0.03 \\
\hline 8 & $\begin{array}{l}\text { Total sediment } \\
\text { potential (TSP) }\end{array}$ & $\%$ & $\begin{array}{c}\text { GOST R 50837.6 } \\
\text { ISO 10307-2 }\end{array}$ & 0.01 & 0.01 & 0.02 & 0.04 \\
\hline
\end{tabular}

According to the results of laboratory tests of samples to determine quality indicators, the fuels submitted according to the classification ISO 8217, GOST R 54299-2010, and GOST 32510-2013 correspond to the brands RMD-80—sample No.1 and 2, RMG-380—sample No.3, and RMK 700—sample No.4.

Table 2 presents the results of laboratory tests to determine the group hydrocarbon composition of the fuels.

Table 2. Analysis of the hydrocarbon group composition of fuel samples.

\begin{tabular}{cccccccc}
\hline $\begin{array}{c}\text { Fuel } \\
\text { Samples }\end{array}$ & $\begin{array}{c}\text { Asphaltenes, } \\
\text { wt. \% }\end{array}$ & $\begin{array}{c}\text { n-Alkanes, } \\
\text { wt. \% }\end{array}$ & $\begin{array}{c}\text { Isoalkane, } \\
\text { wt. \% }\end{array}$ & $\begin{array}{c}\text { Naphthenes, } \\
\text { wt. \% }\end{array}$ & $\begin{array}{c}\text { Alkenes, } \\
\text { wt. \% }\end{array}$ & $\begin{array}{c}\text { Aromatic } \\
\text { Hydrocarbons, } \\
\text { wt. \% }\end{array}$ & $\begin{array}{c}\text { Resins, } \\
\text { wt. \% }\end{array}$ \\
\hline No.1 & - & 71.93 & 18.35 & 2.62 & 5.55 & 1.55 & - \\
No.2 & - & 38.68 & 55.09 & 4.95 & - & 1.28 & - \\
No.3 & 2.53 & 54.14 & 22.74 & 5.43 & 0.57 & 14.12 & 0.47 \\
No.4 & 7.15 & 51.15 & 20.71 & 4.37 & 0.41 & 15.70 & 0.51 \\
\hline
\end{tabular}

Based on the results of determining the group hydrocarbon composition of the studied samples of marine residual fuels, it can be concluded that samples No.1, 3, and 4 are secondary oil refinery products due to the content of alkenes in their composition. Sample No.1 has a high content of normal type alkanes, and sample No.2 contains isoparaffins. The samples are selected in such a way that the components can be mixed to select the compositions of the fuel mixture, with a subsequent determination of the compatibility and stability of the fuels [33].

According to the results obtained to determine the group composition of the study objects, namely samples No.1, 2, 3, and 4, 112 different fuel compositions were prepared with an asphaltene content from 0.5 to $3.5 \mathrm{wt}$. \%, and simultaneously with an n-paraffin content from 55 to $70 \mathrm{wt}$. \%, due to the developed computer program. On the basis of the results of the calculations, 7 series of single-factor experiments were planned and carried out using the newly developed method. In the first series of laboratory experiments, the 
asphaltene content in the fuel mixture corresponded to $0.5 \mathrm{wt}$. \%, while the n-paraffin content varied from 55 to $70 \%$. By analogy, a series of tests have been carried out with asphaltene content of 1.0, 1.5, 2.0, 2.5, 3.0, and $3.5 \mathrm{wt}$. \%. The main indicators of the quality of the fuel compositions obtained and the TSP sediment content values for a series of tests with an asphaltene content of $0.5 \mathrm{wt} . \%$ are presented in Table 3.

Table 3. Group composition, main quality indicators, and TSP values at an asphaltene content of $0.5 \mathrm{wt}$. \% in the fuel composition.

\begin{tabular}{|c|c|c|c|c|c|c|c|c|}
\hline No. & $\underset{\%}{\text { Asphaltenes, }}$ & $\underset{\%}{\text { n-Paraffins, }}$ & $\underset{\%}{\text { Isoparaffins, }}$ & $\begin{array}{c}\text { Aromatic } \\
\text { Hydrocarbons, \% }\end{array}$ & $\begin{array}{c}\text { Density at } 15{ }^{\circ} \mathrm{C}, \\
\mathrm{kg} / \mathrm{m}^{3}\end{array}$ & $\begin{array}{c}\text { Kinematic } \\
\text { Viscosity at } \\
50^{\circ} \mathrm{C}, \mathrm{mm}^{2} / \mathrm{s}\end{array}$ & Sulfur, \% & $\begin{array}{c}\text { TSP } \\
\text { Values, } \%\end{array}$ \\
\hline 1 & & 54.91 & 34.05 & 4.00 & 885.7 & 30.74 & 0.29 & 0.02 \\
\hline 2 & & 55.92 & 32.93 & 4.01 & 883.6 & 29.63 & 0.29 & 0.02 \\
\hline 3 & & 56.94 & 31.82 & 4.01 & 881.5 & 28.57 & 0.29 & 0.02 \\
\hline 4 & & 57.95 & 30.71 & 4.01 & 879.4 & 27.56 & 0.28 & 0.02 \\
\hline 5 & & 58.95 & 29.61 & 4.01 & 877.3 & 26.60 & 0.28 & 0.02 \\
\hline 6 & & 59.95 & 28.51 & 4.01 & 875.2 & 25.69 & 0.28 & 0.02 \\
\hline 7 & & 60.94 & 27.42 & 4.02 & 873.2 & 24.82 & 0.28 & 0.02 \\
\hline 8 & & 61.93 & 26.33 & 4.02 & 871.1 & 24.00 & 0.27 & 0.05 \\
\hline 9 & 0.5 & 62.92 & 25.25 & 4.02 & 869.1 & 23.20 & 0.27 & 0.13 \\
\hline 10 & & 64.06 & 24.00 & 4.02 & 866.7 & 22.33 & 0.27 & 0.20 \\
\hline 11 & & 65.04 & 22.93 & 4.02 & 864.7 & 21.61 & 0.26 & 0.25 \\
\hline 12 & & 66.01 & 21.86 & 4.02 & 862.7 & 20.93 & 0.26 & 0.29 \\
\hline 13 & & 66.98 & 20.80 & 4.02 & 860.7 & 20.28 & 0.26 & 0.33 \\
\hline 14 & & 67.94 & 19.74 & 4.02 & 858.7 & 19.65 & 0.25 & 0.39 \\
\hline 15 & & 69.03 & 19.02 & 3.59 & 853.5 & 17.75 & 0.23 & 0.47 \\
\hline 16 & & 70.05 & 18.66 & 2.85 & 846.4 & 15.40 & 0.20 & 0.58 \\
\hline
\end{tabular}

For each fuel composition, parallel laboratory tests were performed, and the result was given as the arithmetic mean of the two tests.

Laboratory investigations carried out on the basis of the developed method for determining fuel compatibility and stability made it possible to determine the activity of precipitation formation. In the first series of experiments, the asphaltenes content in the composition of fuel mixtures was $0.5 \mathrm{wt}$. \%; only the content of n-paraffins changed. According to the results obtained, presented in Table 3, the asphaltenes precipitation begins when the content of n-paraffins is $62 \mathrm{wt}$. \%, and the most active precipitation is observed at $70 \mathrm{wt}$. \% of the n-paraffin content.

When the paraffin content of normal structure is from 55 to $61 \%$, the reaction is not observed. Due to the approximation, the dependences of the influence of $n$-paraffins on the deposition of agglomerates and heavy hydrocarbon components (1) were obtained with the approximation value $\mathrm{R}^{2}=0.9805$ (Figure 5) with $\mathrm{n}$-paraffin content in the fuel composition in fuels ranging from 62 to $70 \mathrm{wt}$. \% and of asphaltene content $0.5 \mathrm{wt}$. \%:

$$
\mathrm{y}=0.06 \cdot \mathrm{x}-3.6611
$$

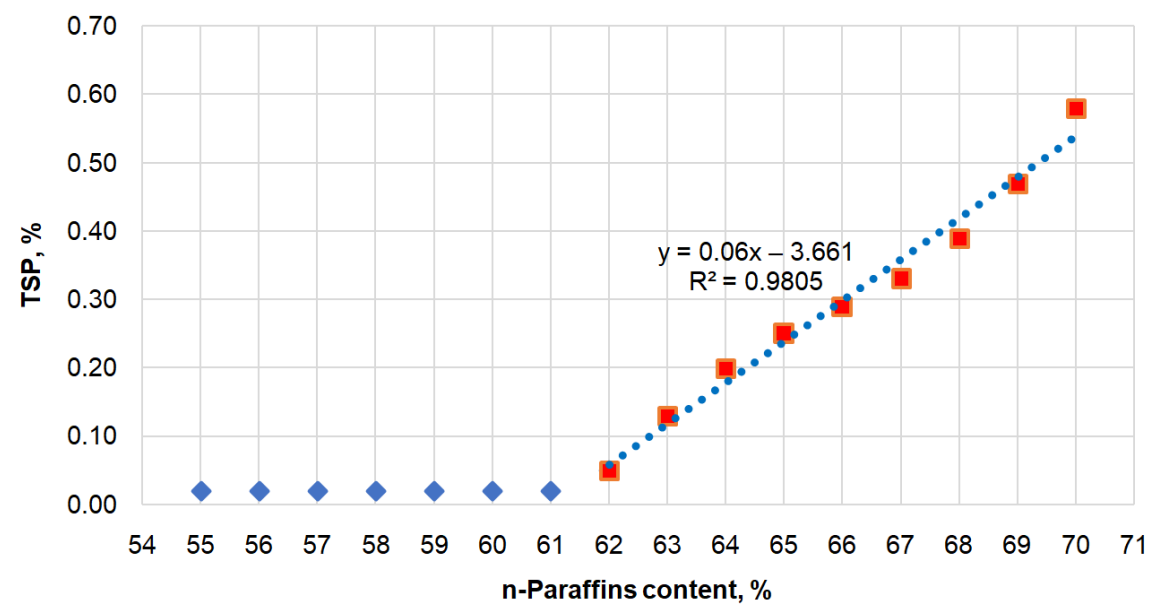

Figure 5. Influence of n-paraffins on the manifestation of incompatibility with an asphaltene content of 0.5 wt. \%. 
It should be noted that laboratory tests were also performed, which were not included in the experimental plan, namely, at a content of $71 \mathrm{wt}$. \% normal-type paraffins, and the TSP value was $0.56 \%$. The result shows that higher values of the TSP values with an increase in the proportion of n-paraffins are not observed, since saturation and maximum sedimentation occur.

Furthermore, the following experimental studies were carried out in a similar way at different asphaltene content, the results of which are shown in Figure 6.

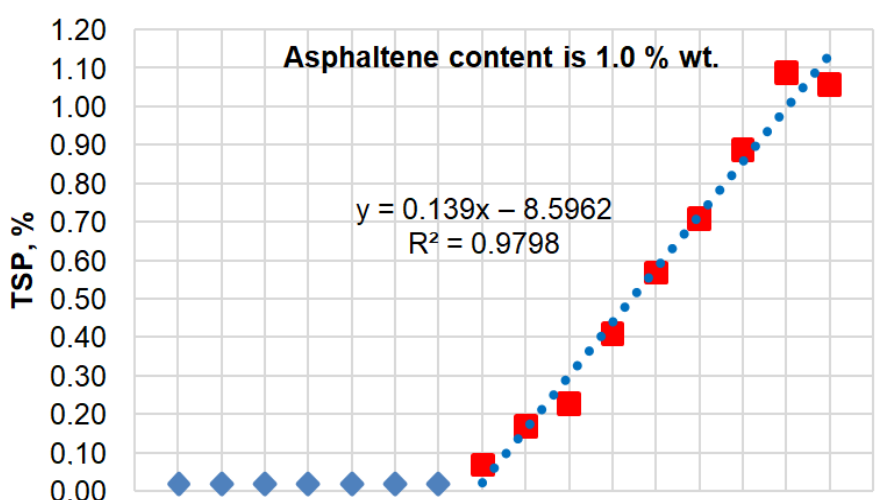

545556575859606162636465666768697071 n-Paraffins content, \%

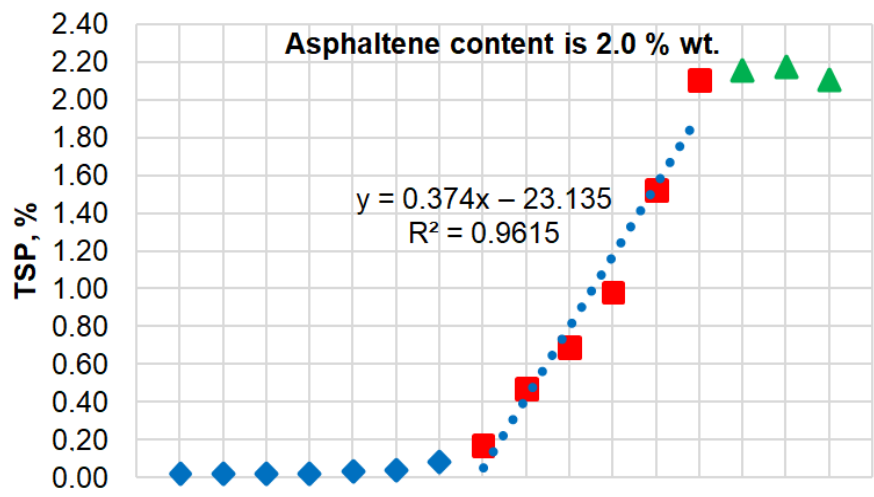

545556575859606162636465666768697071 n-Paraffins content, \%

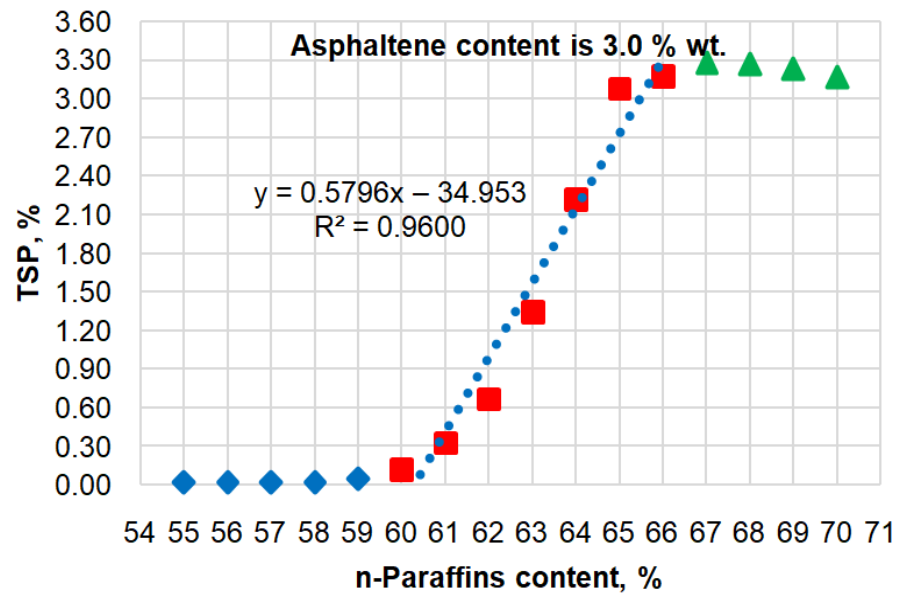

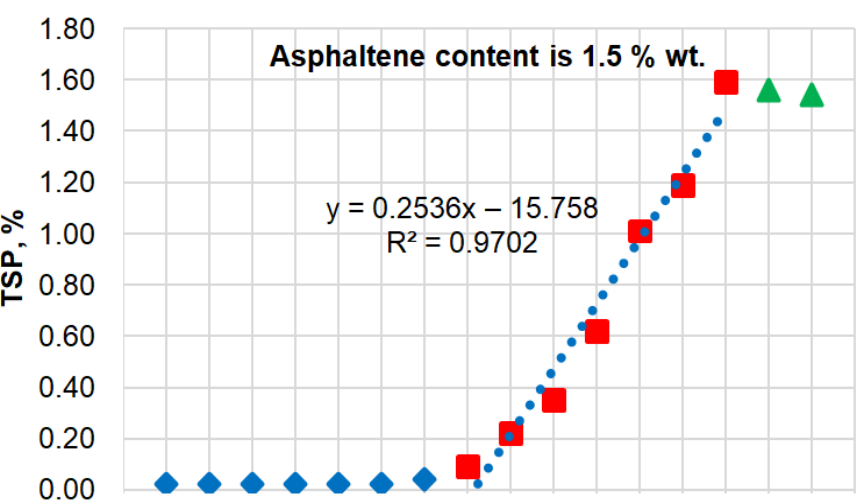

545556575859606162636465666768697071 n-Paraffins content, \%

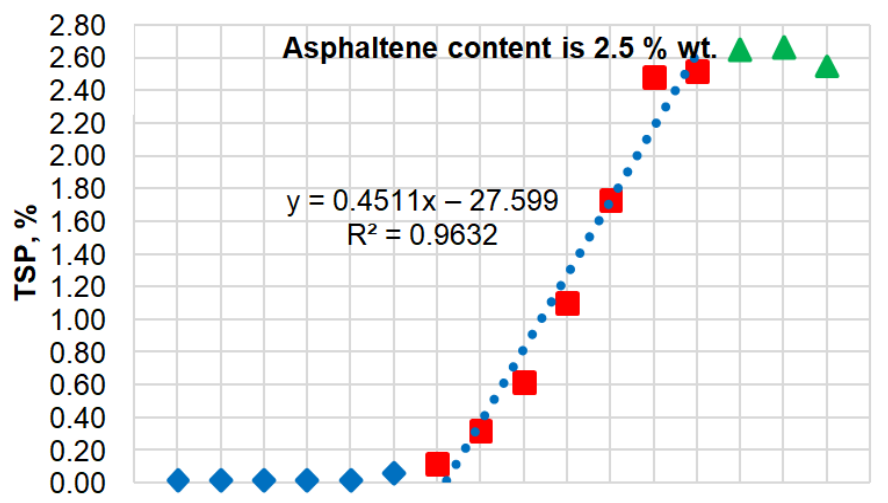

545556575859606162636465666768697071 n-Paraffins content, \%

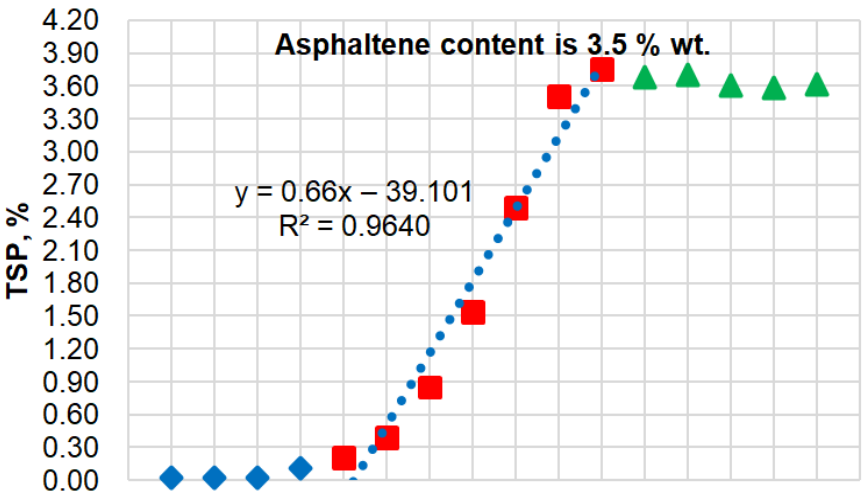

545556575859606162636465666768697071 n-Paraffins content, \%

Figure 6. Dependences of the influence of n-paraffins on total sediments at an asphaltene content from 1.0 to $3.5 \mathrm{wt}$. \%. Blue diamonds-no reaction, Red squares—coagulation process, Green triangles—saturation of the coagulation reaction.

As part of the planning of the experiment, 7 series of single-factor experiments were performed on the laboratory method developed to determine the compatibility and stability 
of fuel components. Based on the results of the studies carried out, the dependences of the influence of n-paraffins on sedimentation activity in fuel mixtures with asphaltene content from 0.5 to $3.5 \%$ with a step of $0.5 \%$ were obtained. A three-dimensional visualization of the research results is shown in Figure 7.

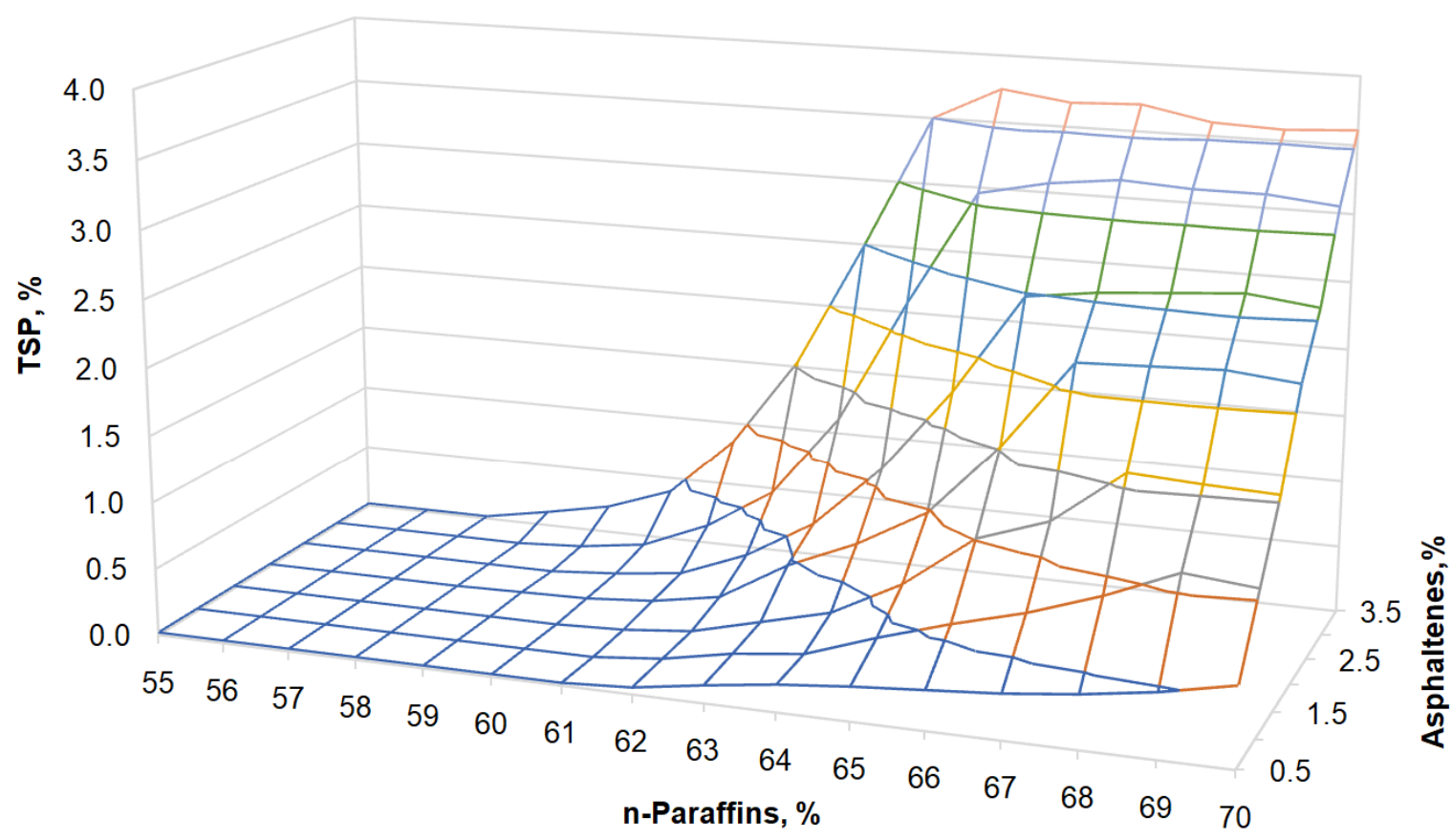

$\square 0.0-0.5 \quad \square 0.5-1.0 \quad \square 1.0-1.5 \quad \square 1.5-2.0 \quad \square 2.0-2.5 \quad \square 2.5-3.0 \quad \square 3.0-3.5 \quad \square 3.5-4.0$

Figure 7. Three-dimensional visualization of the resulting experimental data on the influence of n-paraffins and asphaltenes on the manifestation of incompatibility.

The numerical interpretation of this three-dimensional model of the influence of asphaltenes and n-paraffins on sediment formation is presented in Table 4.

Table 4. Indicators of the influence of n-paraffins and asphaltenes on sedimentation.

\begin{tabular}{cccccccc}
\hline \multirow{2}{*}{ n-Paraffins, \% } & \multicolumn{7}{c}{ Asphaltenes, \% } \\
\cline { 2 - 8 } & $\mathbf{0 . 5}$ & $\mathbf{1 . 0}$ & $\mathbf{1 . 5}$ & $\mathbf{2 . 0}$ & $\mathbf{2 . 5}$ & $\mathbf{3 . 0}$ & $\mathbf{3 . 5}$ \\
\hline 55 & 0.02 & 0.02 & 0.02 & 0.02 & 0.02 & 0.02 & 0.02 \\
56 & 0.02 & 0.02 & 0.02 & 0.02 & 0.02 & 0.02 & 0.02 \\
57 & 0.02 & 0.02 & 0.02 & 0.02 & 0.02 & 0.02 & 0.02 \\
58 & 0.02 & 0.02 & 0.02 & 0.02 & 0.02 & 0.02 & 0.11 \\
59 & 0.02 & 0.02 & 0.02 & 0.03 & 0.02 & 0.05 & 0.21 \\
60 & 0.02 & 0.02 & 0.02 & 0.04 & 0.06 & 0.12 & 0.39 \\
61 & 0.02 & 0.02 & 0.04 & 0.08 & 0.12 & 0.33 & 0.85 \\
62 & 0.05 & 0.07 & 0.09 & 0.17 & 0.32 & 0.65 & 1.54 \\
63 & 0.13 & 0.17 & 0.22 & 0.47 & 0.62 & 1.28 & 2.49 \\
64 & 0.20 & 0.23 & 0.35 & 0.69 & 1.10 & 2.22 & 3.50 \\
65 & 0.25 & 0.41 & 0.62 & 0.98 & 1.73 & 3.08 & 3.75 \\
66 & 0.29 & 0.57 & 1.01 & 1.52 & 2.48 & 3.19 & 3.68 \\
67 & 0.33 & 0.71 & 1.19 & 2.18 & 2.55 & 3.25 & 3.70 \\
68 & 0.39 & 0.89 & 1.59 & 2.20 & 2.59 & 3.22 & 3.60 \\
69 & 0.47 & 1.11 & 1.56 & 2.22 & 2.63 & 3.22 & 3.58 \\
70 & 0.58 & 1.06 & 1.54 & 2.17 & 2.57 & 3.17 & 3.61 \\
\hline
\end{tabular}

On the basis of the experimental data obtained, it is possible to determine the dependencies of the influence of the composition of fuel mixtures on sediments. However, the data presented characterize dependences only for specific contents of the fuel com- 
position, which is difficult to apply in practice, so it is necessary to develop a tool to measure sedimentation activity at different values of n-paraffins and asphaltenes in the ranges considered.

In addition, it is worth noting the resulting trend, namely that the maximum TSP values correlate with the asphaltene content that within $10 \%$ (Table 4 ). This can be explained by the fact that asphaltenes are fully precipitated, where heavy fuel components are also present. To numerically confirm this hypothesis, a correlation-regression analysis of the numerical data received is performed, which is presented in Table 5. Data for maximum TSP values were taken with an asphaltene content of $0.5-3.5 \mathrm{wt}$. \%. The results show a high dependency, and the reliability $\mathrm{R}$ values are close to1.

Table 5. Correlation and regression analysis of the maximum content of TSP and asphaltene.

\begin{tabular}{cc}
\hline Multiple R & 0.999471 \\
\hline R-square & 0.998943 \\
\hline Normalized R-square & 0.998731 \\
\hline Standard error & 0.038477 \\
\hline Significance of $\mathbf{F}$ & $1.24 \mathrm{E}-08$ \\
\hline Student $\boldsymbol{t}$-test & 68.7256 \\
\hline
\end{tabular}

To obtain a universal tool that will allow to determine the manifestation of incompatibility of the components of the fuel mixture at different values of n-alkanes (55-70 wt. \%) and asphaltenes (0.5-3.5 wt. \%) in the ranges considered, a nomogram based on experimental data has been developed and is presented in Figure 8.

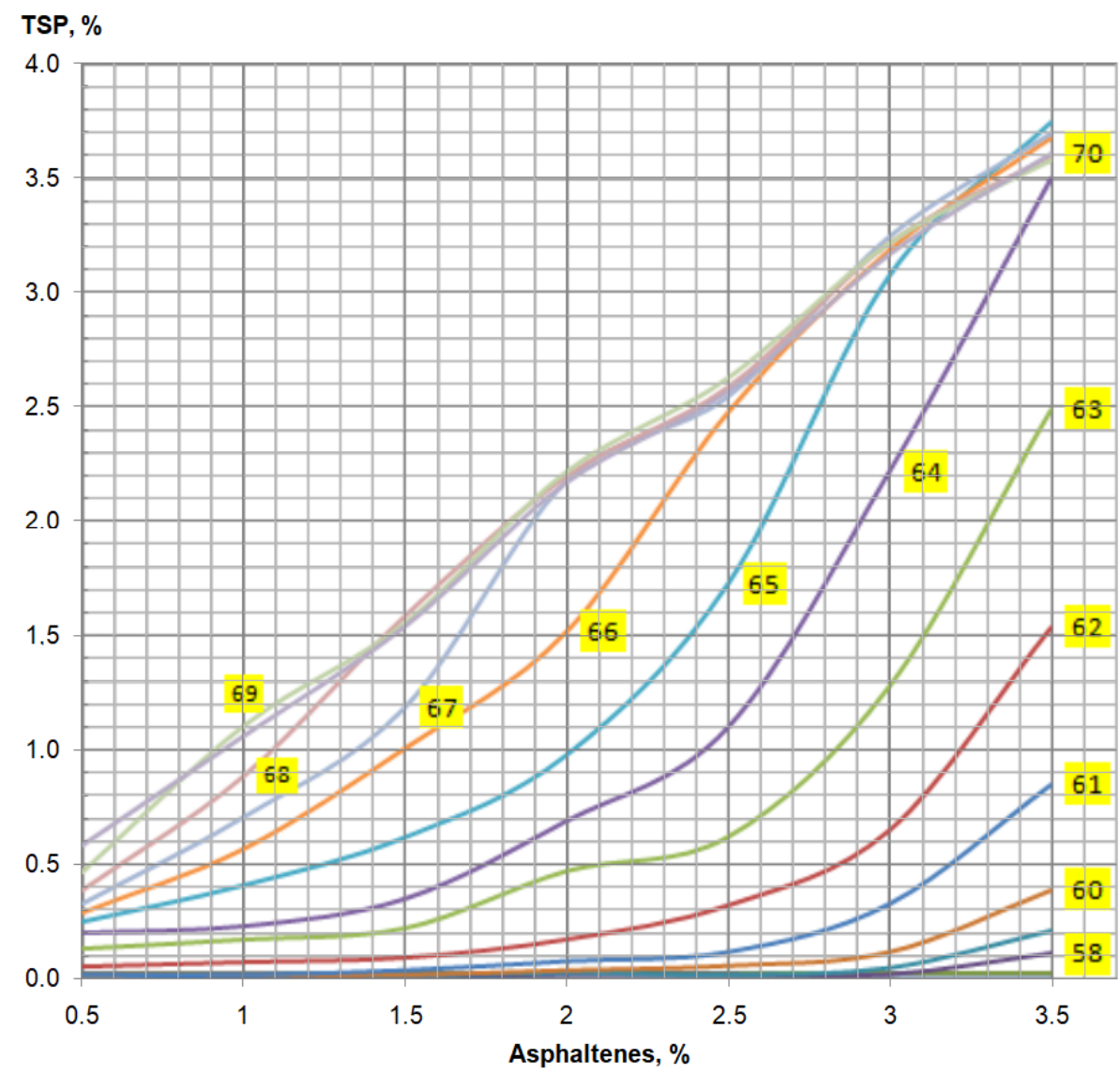

Figure 8. Nomogram of the influence of asphaltene and n-paraffin (marked with percentage) on the activity of precipitation formation. 
The nomogram is built using MS Excel software complex, based on the experimental data obtained. On the X-axis, the asphaltene values are represented in wt. \% and on the Yaxis, and the data on the sediment content TSP in \%. The linear graphs represent n-paraffins in the fuel mixture. The line graphs represent $n$-paraffins in the composition of the fuel mixture. This makes it possible to determine intermediate values of the sediment content.

\section{Discussion}

It is important to note that, today, oil refineries in the EU and Russia are not able to fully provide the consumer with a new type of marine fuel, since this requires a significant revision of the approach to oil refining and spending significant capital investments. Since bunkering companies actively carry out fuel mixing operations, in order to obtain the required quality indicators, the article attempts to assess the viability of this approach and analyze possible solutions.

Based on the data obtained and laboratory tests, several conclusions can be drawn.

First, when the content of n-paraffins is less than $57 \mathrm{wt}$. \% in the composition of fuel mixtures, sedimentation is not observed. The absence of coagulation in Figures 5 and 6 is shown with a blue diamond (rhombus).

Second, the higher the asphaltene content of the fuel mixture, the lower the nparaffin content required for the manifestation of incompatibility. In asphaltene content $0.5 \mathrm{wt} . \%$, incompatibility is observed at $62 \mathrm{wt}$. \% of n-paraffins, and, in asphaltene content, 3.5 wt. \%-n-paraffins 58 wt. \%. The coagulation process in Figures 5 and 6 is shown in red squares.

Finally, the maximum TSP values depend on the asphaltene content. Similar values are observed with an increase in the proportion of n-paraffin. With further increases in n-alkanes, sedimentation remains at the same level. This is due to the fact that, at the critical concentration of n-paraffins, the asphaltenes are fully precipitated and saturated. This is due to the fact that, when the critical concentration of n-paraffins is reached, asphaltenes completely precipitate, and saturation is observed (shown by the green triangles in Figures 5 and 6).

Present results make it possible to calculate the possibility of incompatibility in the mixing of marine residual fuels and their applicability in practice. Due to the obtained dependences of the influence of n-paraffins and asphaltenes on the manifestation of incompatibility, it becomes possible to reduce risks in advance when building a logistics chain for the supply of fuels to marine fuel terminals and oil tank farms. In connection with the absence of asphaltene and n-paraffin content in the list of basic indicators in the international standard ISO 8217, authors will recommend to include these parameters in the standard. This will allow shipowners and buyers to assess in advance the risks of incompatibility and preserve the quality of fuels. Furthermore, the new method considered for determining the compatibility and stability of fuel components makes it possible, before the actual pumping, to obtain data on possible sedimentation and select the optimal component ratio without deterioration of quality. The developed method and the dependencies received are patented $[35,36]$ and introduced into production, namely at the marine fuel terminal of KONTUR St. Petersburg LLC, which is a subsidiary of Baltic Fuel Company LLC.

\section{Conclusions}

(1) A method for determining the compatibility and stability of components of a fuel mixture has been developed and patented. The proposed method makes it possible to determine the stability and compatibility of fuels prior to actual fuel blending in tanks and storage facilities by means of a developed laboratory test algorithm and the calculation of a compatibility index, allowing for determination of quantitative characteristics of precipitation.

(2) The dependence of asphaltenes and n-paraffins in the fuel mixture on precipitation by experimental method is obtained, and correlation and regression analysis of the obtained data is performed. A nomogram has been developed for the dependence of sediment 
formation in the fuel mixture on the concentration of n-paraffins and asphaltenes in the fuel composition, with the content of n-paraffins from 55 to $70 \mathrm{wt}$. \%and asphaltenes from 0.5 to 3.5 wt. \%.

(3) It has been determined that, once maximum TSP values have been reached with a further increase in the n-paraffin content, saturation is observed, and sedimentation values remain at the same level as a result of fully precipitation of asphaltenes in the residual fuel mixture. Maximum TSP values have been found to be correlated with asphaltene content and to not significantly exceed them within $10 \%$.

\section{Patents}

Method of determining compatibility and stability of fuel mixture components. Available online: https:/ / new.fips.ru/ofpstorage/Doc/IZPM/RUNWC1/000/000/002/733/7 48/\%D0\%98\%D0\%97-02733748-00001/document.pdf (accessed on 25 July 2021).

Program for calculating kinematic viscosity, density, sulfur and water content for a mixture of crude oil and petroleum products. Available online: https://new.fips.ru/ ofpstorage/Doc/PrEVM/RUNWPR/000/002/020/613/357/2020613357-00001/document. pdf (accessed on 25 July 2021).

Author Contributions: Conceptualization, R.S., D.M., and I.B.; methodology, R.S.; software, S.I.; validation, D.M., I.B., and T.H.; formal analysis, I.B.; investigation, R.S. and S.I.; resources, S.I. and D.M.; data curation, R.S.; writing—original draft preparation, R.S. and S.I.; writing—review and editing, S.I., I.B. and T.H.; visualization, D.M.; supervision, I.B. and T.H.; project administration, R.S. All authors have read and agreed to the published version of the manuscript.

Funding: The research was performed at the expense of the subsidy for the state assignment in the field of scientific activity for 2021 No. FSRW-2020-0014.

Institutional Review Board Statement: Not applicable.

Informed Consent Statement: Not applicable.

Data Availability Statement: Not applicable.

Acknowledgments: The authors thank Saint Petersburg Mining University for enabling the laboratory experiments. The investigations were carried out using the equipment of the Scientific Centers "Arctic", "Issues of Processing Mineral and Technogenic Resources", and Center for Collective Use of Saint Petersburg Mining University.

Conflicts of Interest: The authors declare no conflict of interest.

$\begin{array}{ll}\text { Abbreviations } \\ \text { GOST } & \text { Russian government standard } \\ \text { CI } & \text { Compatibility index } \\ \text { ISO } & \text { International organization for standardization } \\ \text { SARA } & \text { Saturate, aromatic, resin, and asphaltene } \\ \text { TSA } & \text { Total sediment accelerated } \\ \text { TSP } & \text { Total sediment potential }\end{array}$

\section{References}

1. Stratiev, D.; Dinkov, R.; Shishkova, I.; Yordanov, D. Can we manage the process of asphaltene precipitation during the production of IMO 2020 fuel oil? Erdoel Erdgas Kohle/EKEP 2020, 12, 32-39.

2. Litvinenko, V.S.; Tsvetkov, P.S.; Molodtsov, K.V. The social and market mechanism of sustainable development of public companies in the mineral resource sector. Eurasian Min. 2020, 2020, 36-41. [CrossRef]

3. Litvinenko, V.S. Digital economy as a factor in the technological development of the mineral sector. Nat. Resour. Res. 2020, 29, 1521-1541. [CrossRef]

4. Filatova, I.; Nikolaichuk, L.; Zakaev, D.; Ilin, I. Public-private partnership as a tool of sustainable development in the oil-refining sector: Russian case. Sustainability 2021, 13, 5153. [CrossRef]

5. Dubovoy, E.S.; Shmatkov, A.A.; Shtonda, N.V.; Lyapin, A.Y. On the approach to performance evaluation oil blending stations. Sci. Technol. Oil Oil Prod. Pipeline Transp. 2018, 8, 540-546. [CrossRef] 
6. Demidova, N.P.; Marchenko, A.A.; Onishchenko, O.A. Evaluation of the compatibility of marine heavy fuels. Bull. Kamchatka State Tech. Univ. 2016, 35, 15-20. [CrossRef]

7. Stratiev, D.; Russell, C.; Sharpe, R.; Shishkova, I.; Dinkov, R.; Marinov, I.; Petkova, N.; Mitkova, M.; Botev, T.; Obryvalina, A.; et al. Investigation on sediment formation in residue thermal conversion based processes. Fuel Process. Technol. 2014, 128, 509-518. [CrossRef]

8. Abramova, E.A.; Shuvalov, G.V.; Yasyrova, O.A. Development of a method for assessing the stability and compatibility of marine fuels. Geo-Sibir. 2011, 5, 206-209.

9. Bykova, M.V.; Pashkevich, M.A.; Matveeva, V.A.; Sverchkov, I.P. Assessment and abatement of the soil oil-contamination level in industrial areas. In Proceedings of the International Forum-Contest of Young Researchers: Topical Issues of Rational Use of Natural Resources, St. Petersburg, Russia, 18-20 April 2018; pp. 347-359.

10. Karimov, R.M.; Mastobaev, B.N. Effect of paraffins, resins and asphaltenes on commodity quality of oil. Bashkir Chem. J. 2012, 19, 97-102.

11. Sergeenko, S.R. High Molecular Weight Compounds; Chemistry Press: Moscow, Russia, 1959.

12. Petrovich, N.I.; Ostroukhov, N.N.; Vasilyev, V.V.; Salamatova, E.V.; Strakhov, V.M. Comparison of light fuel-oil fractions produced by semicoking of kukersite shale in a gas generator and in a solid-fuel system. Coke Chem. 2019, 62, 249-257. [CrossRef]

13. Hemmingsen, T.; Hinnaland, D.; Saasen, A. The co-effect of asphaltene on wax precipitation and crystallisation temperature. In Proceedings of the 9th International Oil Field Chemical Symposium, Norway, Geilo, 22-25 March 1998; pp. 1-6.

14. Method for Determining Secondary Residual Products of Oil Refining in Mixed Fuels. Available online: https://new.fips.ru/ Archive/PAT/2011FULL/2011.08.10/DOC/RUNWC1/000/000/002/426/116/DOCUMENT.PDF (accessed on 25 July 2021).

15. Method for Determining Stability Factor of Fuel Compositions Containing Residual Products of Oil Processing. Available online: https:/ / new.fips.ru/Archive/PAT/2007FULL/2007.09.10/DOC/RUNWC1/000/000/002/305/836/DOCUMENT.PDF (accessed on 25 July 2021).

16. Method of Determining Compatibility of Components of Fuel Mixture. Available online: https://new.fips.ru/Archive/PAT/20 12FULL/2012.02.27/DOC/RUNWC1/000/000/002/444/005/DOCUMENT.PDF (accessed on 25 July 2021).

17. Fuel Compatibility and Stability Analyzer. Available online: https://patentscope.wipo.int/search/en/detail.jsf?docId=WO20181 85520 (accessed on 25 July 2021).

18. Pelenitsyna, O.A.; Litvinenko, N.A.; Gaile, A.A. Development of optimal formulations of ship low-viscosity and residual fuels on the basis of commodity oil products. Bull. SPBSIT 2018, 45, 30-36.

19. Martin, C.W.G. The stability and compatibility of fuel oils. In Proceedings of the 3rd World Petroleum Congress, The Hague, The Netherlands, 28 May 1951; pp. 66-75.

20. Holmes, J.W.; Bullin, J.A. Fuel oil compatibility probed. Hydrocarb. Process. 1983, 62, 101-103.

21. Murzakov, R.M.; Sabanenkov, S.A.; Syunyaev, Z.I. Influence of petroleum resins on colloidal stability of asphaltene-containing disperse systems. Chem. Technol. Fuels Oils 1980, 16, 674-677. [CrossRef]

22. Kassinger, R. Fuel blending-How to minimize risk of incompatibility. In Proceedings of the SPE 6th International Conference on Stability and Handling of Liquid Fuels, Vancouver, BC, Canada, 13-17 October 1997; pp. 489-502.

23. Evdokimov, I.N. Problems of Incompatibility of Oils When They are Mixed; National University of Oil and Gas "Gubkin University" Press: Moscow, Russia, 2008.

24. Mitusova, T.N.; Kondrasheva, N.K.; Lobashova, M.M.; Ershov, M.A.; Rudko, V.A. Influence of dispersing additives and blend composition on stability of marine high-viscosity fuels. J. Min. Inst. 2017, 228, 722-725.

25. Gulvaeva, L.A.; Khavkin, V.A.; Shmel'kova, O.I.; Mitusova, T.N.; Ershov, M.A.; Lobashova, M.M.; Nikul'shin, P.A. Production technology for low-sulfur high-viscosity marine fuels. Chem. Technol. Fuels Oils 2019, 54, 759-765. [CrossRef]

26. Kondrasheva, N.K.; Rudko, V.A.; Nazarenko, M.Y.; Gabdulkhakov, R.R. Influence of parameters of delayed asphalt coking process on yield and quality of liquid and solid-phase products. J. Min. Inst. 2020, 241, 97-104. [CrossRef]

27. Wiehe, I.A.; Kennedy, R.J. The oil compatibility model and crude oil incompatibility. Energy Fuels 2000, 14, 56-59. [CrossRef]

28. Wiehe, I.A.; Yarranton, H.W.; Akbarzadeh, K.; Rahimi, P.M.; Teclemariam, A. The paradox of asphaltene precipitation with normal paraffins. Energy Fuels 2005, 19, 1261-1267. [CrossRef]

29. Kopteva, A.V.; Koptev, V.Y. Automated monitoring system for asphaltene-resin-paraffin deposits in main oil pipelines. Int. J. Appl. Eng. Res. 2016, 11, 2191-2198.

30. Cheremisina, O.V.; Ponomareva, M.A.; Sagdiev, V.N. Thermodynamic characteristics of sorption extraction and chromatographic separation of anionic complexes of erbium and cerium with Trilon B on weakly basic anionite. Russ. J. Phys. Chem. 2016, 90, 664-670. [CrossRef]

31. Cheremisina, O.; Kulagin, V.; El-Saleem, S.; Nikulchev, E. Multisensory gas analysis system based on reconstruction attractors. Symmetry 2020, 12, 964. [CrossRef]

32. Korshunov, G.I.; Eremeeva, A.M.; Drebenstedt, C. Justification of the use of a vegetal additive to diesel fuel as a method of protecting underground personnel of coal mines from the impact of harmful emissions of diesel-hydraulic locomotives. J. Min. Inst. 2021, 247, 39-47. [CrossRef]

33. Prakoso, A.; Punase, A.; Klock, K.; Rogel, E.; Ovalles, C.; Hascakir, B. Determination of the stability of asphaltenes through physicochemical characterization of asphaltenes. In Proceedings of the SPE Western Regional Meeting, Anchorage, AK, USA, 23 May 2016; pp. 1-20. 
34. Povarov, V.G.; Lopatnikov, A.I. A simple multisensor detector based on tin dioxide in capillary gas chromatography. J. Anal. Chem. 2016, 71, 901-906. [CrossRef]

35. Method of Determining Compatibility and Stability of Fuel Mixture Components. Available online: https://new.fips.ru/ ofpstorage/Doc/IZPM/RUNWC1/000/000/002/733/748/\%D0\%98\%D0\%97-02733748-00001/document.pdf (accessed on 25 July 2021).

36. Program for Calculating Kinematic Viscosity, Density, Sulfur and Water Content for a Mixture of Crude Oil and Petroleum Products. Available online: https:/ /new.fips.ru/ofpstorage/Doc/PrEVM/RUNWPR/000/002/020/613/357/2020613357-000 01/document.pdf (accessed on 25 July 2021). 